\title{
Studi Kelayakan Pengadaan Alat Picture Archiving and Communication System di RSUP Dr. Soeradji Tirtonegoro Klaten
}

\author{
Retno Dyah Parwitasari* \\ *Penulis Korespondensi: retnodyah_parwitasari@yahoo.com \\ * Rumah Sakit Umum Pusat Dr. Soeradji Tirtonegoro Klaten, Jawa Tengah, Indonesia

INDEXING ABSTRACT \\ Keywords: \\ Hospital of Klaten; \\ Feasibility Study; \\ Teleradiology; \\ Picture Archiving And \\ Communication System \\ (PACS)

\begin{abstract}
This study aimed to analyze the appropriateness of the technical aspects, the financial markets and the procurement plan PACS.Penelitian this is a case study located at the General Hospital Center (Dr) the technical aspects and the market has met. From the aspect of finance, investment appraisal results using PP is 2 years 239.4 days, less than a specified useful life, which is 5 years means that investment is worth it. The results of the NPV method is Rp.1.875.508.315,25, meaning that the investment is worth it. The results of the method IRR is $27 \%$, greater than the specified rate of return of $6.5 \%$, meaning that the investment is worth it. Thus we can conclude the investment project in the PACS instrument $d r$. Soeradji Tirtonegoro Klaten feasible.
\end{abstract} \\ Soeradji Tirtonegoro Klaten. This study found that investment decisions PACS instrument in terms of
}

\author{
Kata kunci: \\ RSUP Klaten; \\ Studi kelayakan; \\ Teleradiologi; \\ Picture Archiving and \\ Communication System \\ (PACS)
}

\begin{abstract}
Penelitian ini bertujuan untuk menganalisis layak tidaknya dari aspek teknis, pasar dan keuangan terhadap rencana pengadaan alat PACS.Penelitian ini adalah penelitian studi kasus yang berlokasi di Rumah Sakit Umum Pusat (RSUP) Soeradji Tirtonegoro Klaten. Penelitian ini menemukan bahwa keputusan investasi alat PACS ditinjau dari aspek teknis dan pasar telah memenuhi. Dari aspek keuangan, hasil penilaian investasi menggunakan metode PP adalah 2 tahun 239,4 hari, kurang dari masa manfaat yang ditentukan, yaitu 5 tahun artinya investasi layak. Hasil metode NPV adalah Rp.1.875.508.315,25, artinya investasi layak. Hasil metode IRR adalah $27 \%$, lebih besar dari rate of return yang ditentukan yaitu $6,5 \%$, artinya investasi layak. Dengan demikian dapat disimpulkan proyek investasi alat PACS di RSUP dr. Soeradji Tirtonegoro Klaten layak.
\end{abstract}

(C) 2017 JMMR. All rights reserved

Article history: Received 10 Okt 2016; Revised 15 Des 2016; Accepted 4 Jan 2017

\section{PENDAHULUAN}

Ketidakmerataan distribusi tenaga kesehatan di Indonesia merupakan salah satu hambatan dalam upaya peningkatan akses terhadap layanan kesehatan. Tenaga kesehatan menumpuk di daerah urban sementara Daerah Terpencil, Perbatasan dan Kepu-lauan (DTPK) mengalami kekurangan tenaga. $\frac{1}{-}$ Pada saat ini ketersediaan tenaga pela-yanan radiologi masih belum merata di fasilitas pelayanan kesehatan sekunder khususnya rumah sakit kelas C dan D terutama di daerah perbatasan, terpencil dan kepu-lauan (DTPK). Berdasarkan data Sistem Informasi Rumah Sakit (SIRS) online Kementerian Kesehatan R.I pada tanggal 1 Januari 2014, terdapat 2.228 rumah sakit baik pemerintah maupun swasta di Indonesia dan hanya tersedia 1.911 rumah sakit yang telah memiliki Dokter Spesialis Radiologi. Dari angka tersebut, sebesar 69,5\%
Dokter Spesialis Radiologi berada di Pulau Jawa dan jumlah terendah berada di Provinsi Sumatra Barat, Kepulauan Riau dan Bengkulu.

Berkaitan dengan ketidakmerataan tenaga kesehatan dan oleh karena kemajuan teknologi informasi saat ini telah berkembang sangat pesat, maka pemanfaatan perangkat elektronik bidang kesehatan memberikan alternatif dalam meningkatkan akses dan mutu pelayanan kesehatan di Indonesia. Salah satu alternatif adalah dengan mengembangkan teknologi teleradiologi.

Standar akreditasi Komite Akreditasi Rumah Sakit versi 2012 Asesmen Pasien 6.4, menetapkan jangka waktu pelaporan hasil pemeriksaan radiologi dan diagnostik imaging untuk pemeriksaan cito / kritis, akhir minggu dan diluar jam kerja di rumah sakit. Sesuai standar pelayanan minimal, khusus pemerik-saan cito / kritis harus sudah dilakukan ekspertise oleh dokter 
spesialis radiologi dalam jangka waktu maksimal 1 jam. Teleradiologi dapat memberikan manfaat dalam peningkatan ketepatan dan kecepatan rujukan diagnosis medis serta konsultasi citra radiografi antar fasilitas pelayanan kesehatan jarak jauh. Pengembangan teleradiologi dilaksanakan dalam rangka memenuhi pelayanan rujukan ekspertis gambar radiografi yang berkualitas terutama bagi fasilitas kesehatan yang belum memiliki Dokter Spesialis Radiologi.

RSUP dr Soeradji Tirtonegoro mulai berdiri sejak tahun 1927 dan sesuai Rencana Strategis Bisnis tahun 2015-2019 mencanangkan menjadi rumah sakit umum kelas A pada tahun 2019. Sejalan dengan itu RSUP dr. Soeradji Tirtonegoro sebagai salah satu rumah sakit vertikal di jajaran Kementrian Kesehatan Republik Indonesia, mencoba mensukseskan program Kementrian Kesehatan dengan menjadi rumah sakit pemberi pelayanan teleradiologi sebagai salah satu layanan unggulan pada tahun 2017. Dengan sumber daya yang ada yaitu 4 orang dokter spesialis radiologi, RSUP dr. Soeradji Tirtonegoro berharap mampu mengembangkan pelayanan teleradiologi. Untuk mencapai tujuan tersebut perlu adanya penyesuaian kelengkapan sarana prasarana, dimana salah satunya adalah pengadaan Picture Archiving and Commu-nication System (PACS) karena tanpa ada PACS yang baik kehandalan teleradiologi tidak akan dapat tercapai.-

Di dalam Peraturan Menteri Kesehatan Republik Indonesia nomor 1014 tahun 2008 tentang standar pelayanan radiologi diagnostik di sarana pelayanan kesehatan disebutkan bahwa salah satu peralatan radiologi yang harus ada di rumah sakit klas $\mathrm{A}$ adalah Picture Archiving Communication System (PACS). Berdasarkan masalah-masalah yang ada, apakah rencana pengadaan alat PACS di Rumah Sakit Umum Pusat dr Soeradji Tirtonegoro Klaten layak dari aspek teknis, pasar dan keuangan?.

\section{METODE PENELITIAN}

Jenis penelitian ini adalah studi kasus. Responden penelitian ini adalah kepala bidang pelayanan medik dan kepala instalasi radiologi. Obyek penelitian ini adalah instalasi radiologi. Penelitian dilakukan pada bulan April - Mei 2016 di RSUP dr. Soeradji Tirtonegoro Pengumpulan data berasal dari dua sumber data, yaitu : dokumen / rekaman arsip dan wawancara. Studi kelayakan melalui pendekatan aspek teknis, aspek pasar dan aspek keuangan dengan menggunakan metode Payback Period (PP), Net Present Value (NPV) dan Internal Rate of Return (IRR). $-\frac{3}{-}$

\section{HASIL DAN PEMBAHASAN}

\section{Analisis aspek teknis}

Tujuan untuk mendapatkan gambaran kelayakan terhadap kapasitas ekonomis, jenis teknologi yang paling cocok, lokasi yang paling menguntungkan dan pemenuhan ketenagaan.

\section{Pemilihan jenis alat PACS}

Ada 2 jenis alat yang ditawarkan kepada rumah sakit dr Soeradji Tirtonegoro, yaitu local PACS dan cloud PACS. Diantara 2 jenis alat tersebut, cloud PACS mempunyai banyak kelebihan dibanding local PACS serta sesuai dengan yang dibutuhkan oleh rumah sakit dr Soeradji Tirtonegoro.

Adapun standar fasilitas minimal yang dibutuhkan, yaitu : Spesifikasi Perangkat Komputer: (a) Fasyankes perujuk (diampu), Perangkat Keras meliputi: Pentium ${ }^{\circledR}$ Dual core Processor -Equivalent or Higher, 2 GB RAM, Resolusi Monitor 1024*768, 32 bit true Color, UPS; Perangkat lunak meliputi: Windows 7TM Professional / Ultimate 32 bit / Windows 8, Internet Explorer 9.0 or Higher, Chrome v22, Software teleradiologi (Upload), Anti virus firewall, Antivirus \& Anti-spy ware Internet; Network meliputi: Network speed 2 Mbps, 100/1000 Mbps Ethernet card; Modalitas meliputi: Standard DICOM; Printer: Dot matrix/laser printer; (b) Server RSUP dr. Soeradji Tirtonegoro (pengampu), Perangkat Keras meliputi: Intel Quad core Xeon Processor, $800 \mathrm{MHz} 2,4 \mathrm{~GB}$ RAM (Higher RAM recommended if number of user exceed 25), $500 \mathrm{MB}$ ruang hardisk kosong untuk aplikasi, 1 TB ruang hardisk kosong untuk data/citra, Resolusi Monitor 1024*768, 32 bit true Color, UPS; Perangkat lunak, meliputi: Windows 2008 server (enterprise atau web server atau data, center edition Internet Explorer 9.0 or Higher, Chrome v22, Internet 
Information Server 7.0, 3) PACS server; Network: Network speed 4 Mbps, Workstation RSUP dr. Soeradji Tirtonegoro (pengampu); Perangkat Keras meliputi: Pentium ${ }^{\circledR}$ Dual core Processor-Equivalent or Higher, 2 GB RAM, Resolusi Monitor 1024*768,32 bit true Color (general radiologi), Resolusi Monitor 5 MP FDA approved, 32 bit true Color, (mammografi), UPS; Perangkat lunak meliputi: Windows $7^{\mathrm{TM}}$ Professional / Ultimate 32 bit / Windows 8, Internet Explorer 9.0 or Higher, Chrome v22, Software teleradiologi (Upload), Anti virus firewall, Antivirus \& Anti spy ware Internet; Network: Network speed 2 Mbps, 100/1000 Mbps Ethernet card, Viewer (browser) RSUP dr. Soeradji Tirtonegoro (pengampu), Tablet dengan Resolusi Monitor 1024*768, Network speed 2 Mbps.

Adapun spesifikasi PACS adalah sebagai berikut: (1) Mampu mengupload format DICOM, bmp, png, tiff, gif, jpeg, txt, pdf, doc, xls, avi, mpeg, mp4, flv, wmv, mov; (2) Pada daftar pasien tersedia opsi pemilihan yang fleksibel baik menurut tanggal upload, status expertis, yankes yang diampu, modalitas maupun dokter pengirim; (3) Dapat mengupload riwayat pasien atau dokumen pendukung lain seperti hasil laboratorium; (4) Dapat dilihat melalui WEB; (5) Dapat dilihat dengan dicom viewer dengan menu MPR, multiframe, mampu untuk membandingkan foto; (6) Tersedia fitur Turn Around Time (TAT); (7) Dapat dihubungkan dengan DICOM viewer dari merek lain; (9) dapat digunakan untuk pengembangan teknologi radiologi; (9) Citra dapat diarahkan ke dokter tertentu untuk dilakukan ekspertis sehingga dapat dilakukan penjadwalan untuk dokter spesialis radiologi; (10) Ada menu untuk menandai prioritas citra sehingga pada pasien emergensi akan cepat di ekspertis; (11) Tersedia template yang dapat di atur sedemikian rupa; (12) Ada laporan melalui email setelah citra di lakukan ekspertis; (13) Ada menu untuk melihat statistik citra yang diupload, diekspertis, jumlah citra yang diekspertis dokter tertentu; (14) Adanya tingkatan kewenangan akses untuk melihat citra, mengekspertis, mengupload dokumen pendukung dan melakukan administrasi; (15) Dapat memodifikasi kewenangan user baik dokter spesialis radiologi, radiografer, tenaga Informasi dan Teknologi maupun dokter pengirim.

Tabel 1. Perbandingan local PACS dan Cloud PACS

\begin{tabular}{lll}
\hline \multicolumn{1}{c}{ Local PACS } & \multicolumn{1}{c}{ Cloud PACS } \\
\hline - $\begin{array}{l}\text { Membutuhkan Server lokal dan biaya hardware serta } \\
\text { pengelolaan sistem Informasi dan Teknologi }\end{array}$ & $\begin{array}{l}\text { Tidak membutuhkan Server lokal dan biaya } \\
\text { hardware serta pengelolaan sistem Informasi dan } \\
\text { Teknologi } \\
\text { - } \begin{array}{l}\text { Membutuhkan pengelolaan software lokal. Upgrade } \\
\text { dan update secara manual }\end{array}\end{array}$ & $\begin{array}{l}\text { Tidak membutuhkan pengelolaan software lokal. } \\
\text { upgrade dan } \text { update secara otomatis }\end{array}$ \\
- $\begin{array}{l}\text { Pengaturan user dalam pembacaan hasil terjadi } \\
\text { tumpang tindih }\end{array}$ & - & Tidak terjadi karena tiap user punya kode pribadi \\
- $\begin{array}{l}\text { Resiko data dicuri, terkena virus atau hilang } \\
\text { - Pembacaan hasil terbatas di rumah sakit, hanya di } \\
\text { komputer pribadi }\end{array}$ & - $\begin{array}{l}\text { Tidak terjadi } \\
\text { Pembacaan hasil bisa dimana saja, kapan saja, di } \\
\text { perangkat apa saja }\end{array}$ \\
\hline
\end{tabular}




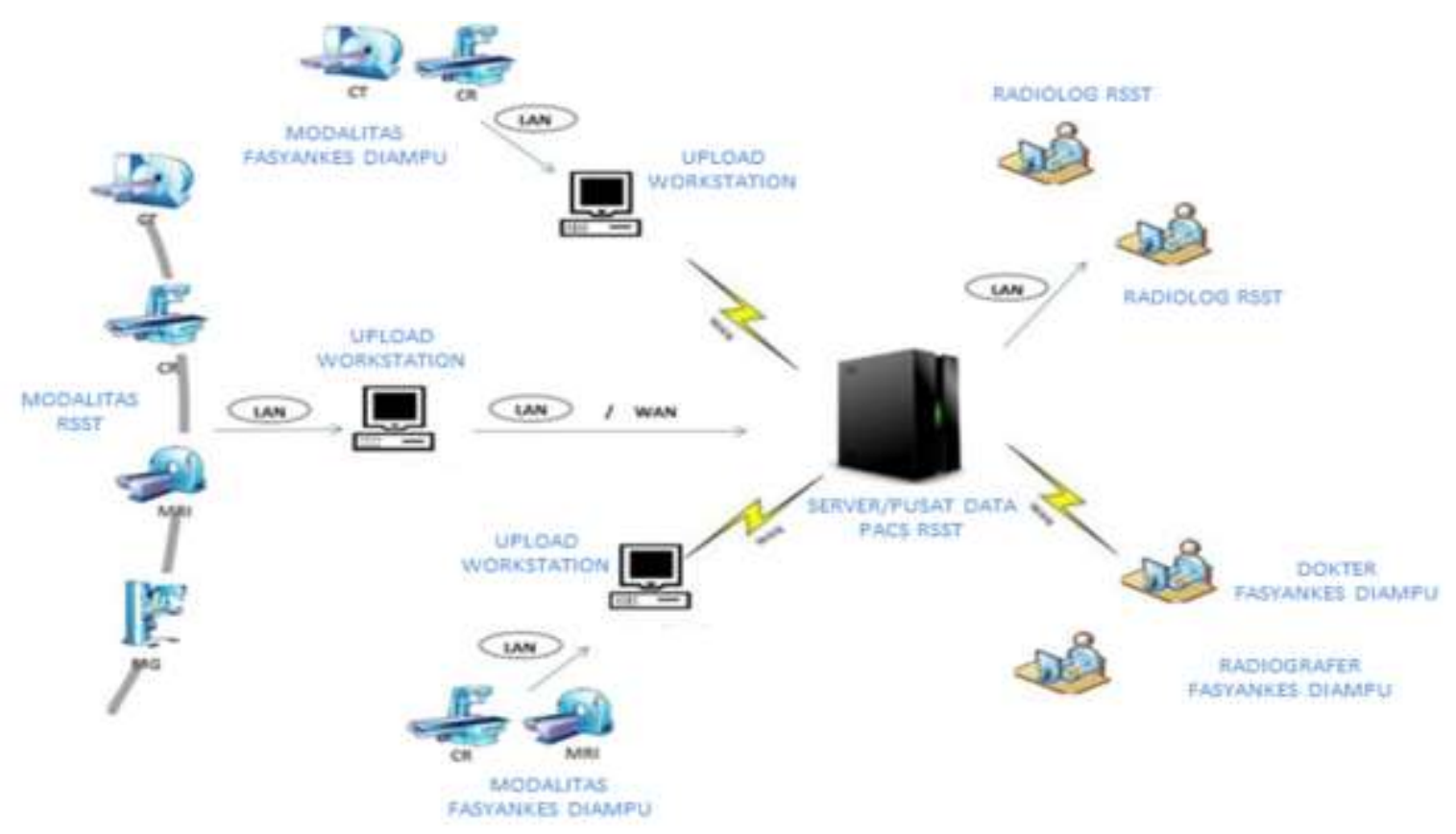

Gambar 1. Skema Rujukan Teleradiologi

Pelayanan purna jual

Pelatihan untuk operator akan diberikan oleh penyedia alat sampai benar-benar mahir. Apabila terjadi kerusakan alat, penyedia alat memberikan jaminan / respon time dengan cepat melalui sistem remote service. Apabila terjadi masalah di hardware sehingga tidak bisa ditangani melalui sistem remote service, kedatangan teknisi secara onsite maksimal selama 3 x 24 jam. Apabila diperlukan akan diberikan backup alat. Selain itu juga terdapat garansi suku cadang dan jasa pemeliharaan selama 1 tahun.

Lokasi

Sesuai keputusan Menteri Kesehatan Republik Indonesia nomor 1014/Menkes/SK/XI/2008 tentang standar pelayanan radiologi diagnostic di sarana pelayanan kesehatan, standar ruang PACS adalah: (1) Ukuran: minimal $3 \mathrm{~m}$ (p) x 3 m (1) x 2,8 m (t); (2) Dapat menampung : - tempat printer, processing dan rekam medik elektronik; (3) Dilengkapi dengan AC. Suhu dan kelembaban disesuaikan kebutuhan alat.

Alat penunjang yang dibutuhkan adalah jaringan Local Area Network, koneksi internet, meja dan kursi untuk operator. Sedangkan bagi rumah sakit yang diampu cukup menyediakan perangkat komputer dan alat penunjang yang dibutuhkan adalah jaringan Local Area Network, koneksi internet, meja dan kursi untuk operator. Secara teknis, pemasangan peralatan berada dibawah tanggung jawab pemasok peralatan.

Rumah sakit dr Soeradji Tirtonegoro sebagai rumah sakit pengampu, sudah mempersiapkan ruang di instalasi radiologi seluas $22,4 \mathrm{~m} 2$ untuk memenuhi kebutuhan ruangan (workstation) bagi perangkat keras maupun perangkat lunak alat PACS. Direncanakan menggunakan ruang yang saat ini digunakan untuk ruang pembacaan radiologi dengan mengalihkan beberapa mebelair yaitu 2 almari dan 1 meja ke ruang lain. Denah / layout ruang yang dipersiapkan untuk alat PACS disajikan pada Gambar 2 dan 3. 



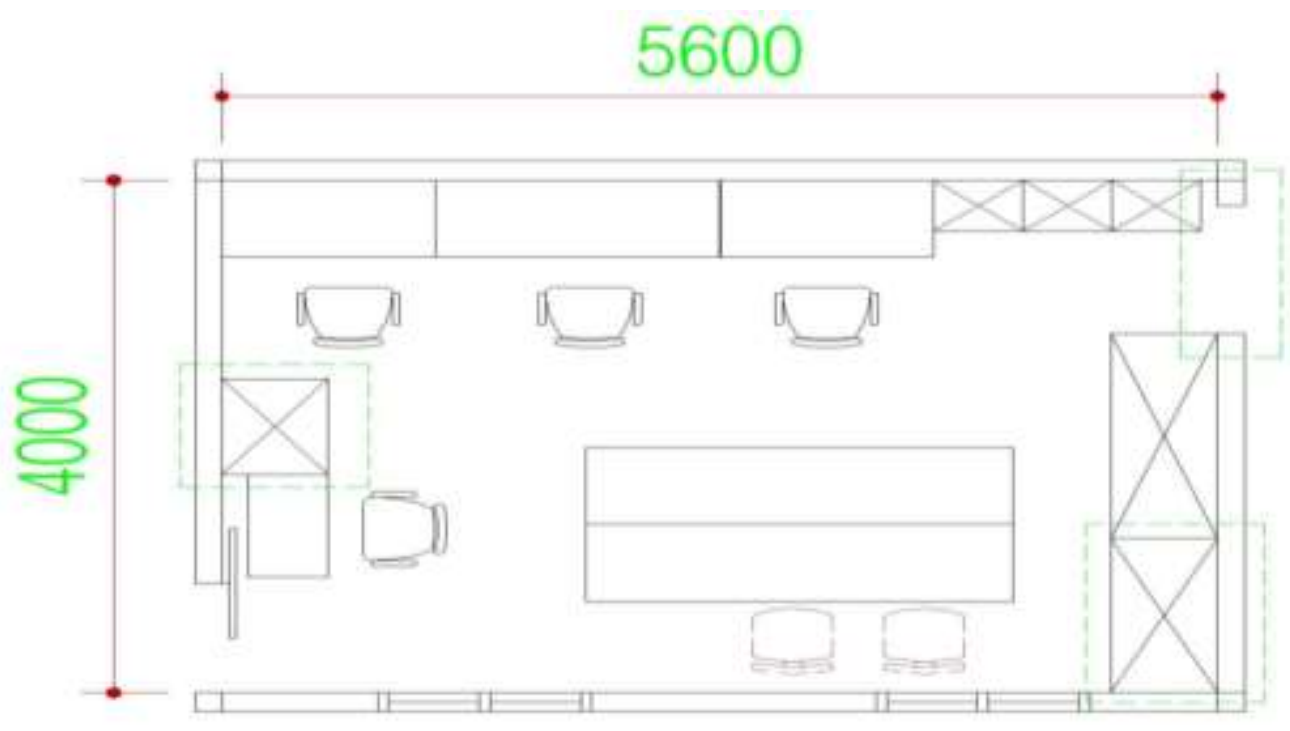

\section{DENAH EKSISTING}

Gambar 2. Denah ruang saat ini

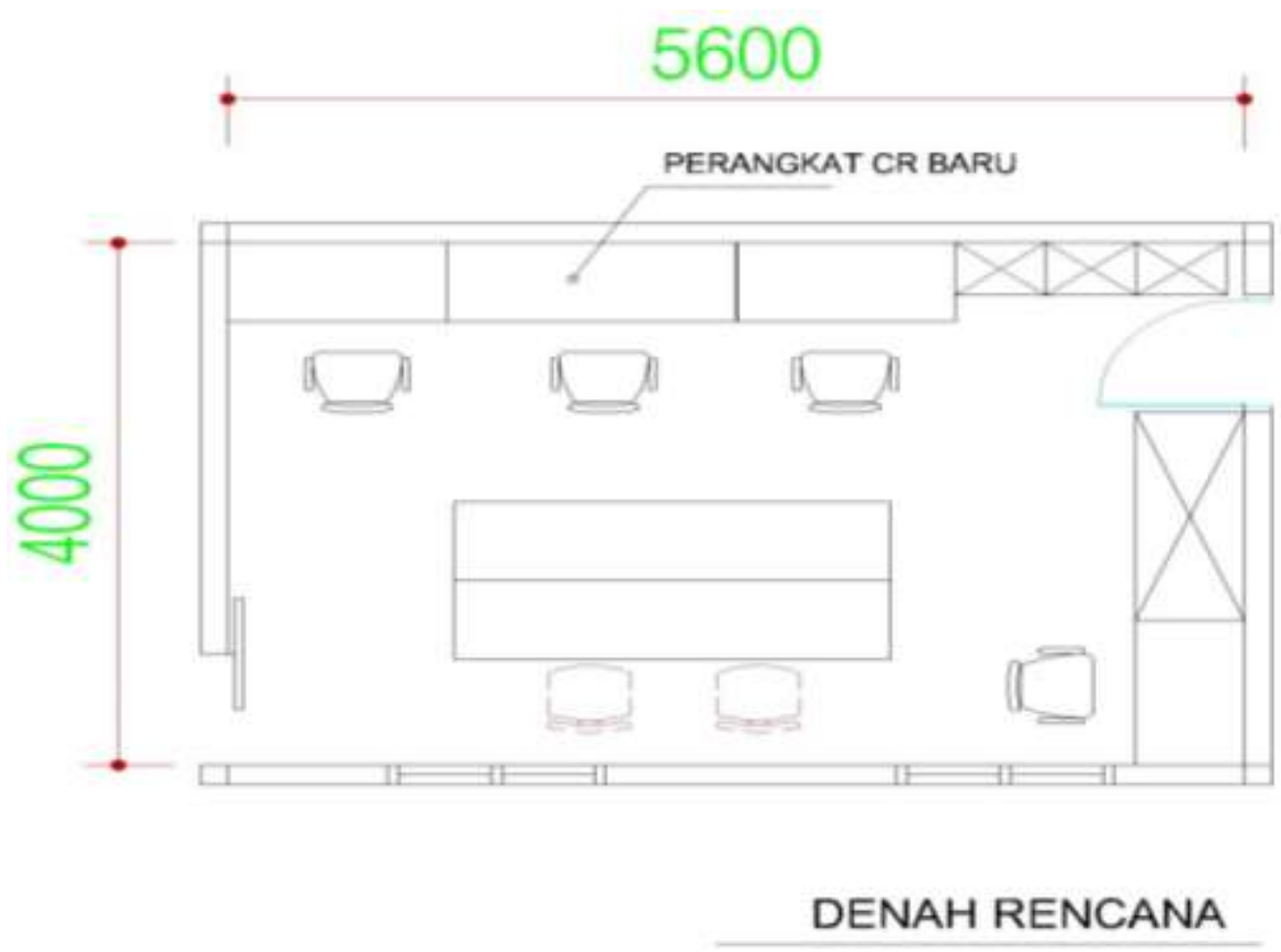

Gambar 3. Denah ruang untuk penempatan alat PACS

Ketenagaan 
Jenis dan jumlah tenaga yang dibutuhkan dalam instalasi radiologi diagnostik berdasarkan jenis sarana pelayanan kesehatannya yaitu rumah sakit kelas A atau setara, adalah sesuai tabel dibawah.

Tabel 2. Persyaratan jenis dan jumlah tenaga medis dan radiografer rumah sakit kelas $A$ atau setara

\begin{tabular}{lcc}
\hline Jenis Tenaga & Persyaratan & $\begin{array}{c}\text { Jumlah } \\
\text { RS kelas A }\end{array}$ \\
\hline Spesialis radiologi & Memiliki SIP & 6 orang \\
& D3 Teknik & \\
Radiografer & Radiologi & 2 orang/alat \\
& Memiliki & \\
\hline
\end{tabular}

Sumber: Keputusan Menteri Kesehatan Republik Indonesia nomor 1014 tahun 2008 tentang standar pelayanan radiologi diagnostik di sarana pelayanan kesehatan

Tabel 3. Jenis dan jumlah tenaga medis dan radiografer di rumah sakit $\mathrm{dr}$. Soeradji

Tirtonegoro saat ini

\begin{tabular}{lcc}
\hline Jenis Tenaga & Persyaratan & Jumlah \\
\hline Spesialis radiologi & Memiliki SIP & 4 orang \\
Radiografer & D3 Teknik Radiologi & 13 orang \\
& Memiliki SIKR & \\
\hline
\end{tabular}

Sumber : Data pedoman pengorganisasian instalasi radiologi tahun 2015

Analisis aspek pasar

Tujuan untuk mendapatkan gambaran kelayakan terhadap permintaan potensial, kemungkinan adanya persaingan, serta perkiraan penjualan yang dapat dicapai aspek pasar meliputi perkiraan permintaan, unit cost dan tarif.. Investasi dari aspek pasar layak jika kecenderungan permintaan terus meningkat, tarif dibawah harga pesaing dan spesifikasi produk sebanding dengan pesaing. Gambaran kelayakan terhadap permintaan potensial menggunakan alat PACS bisa diasumsikan dengan kinerja instalasi radiologi rumah sakit dr. Soeradji Tirtonegoro. Perkiraan umur ekonomis dan tarif yang layak.

Untuk mengoperasionalkan alat tersebut, dibutuhkan tarif. Komponen penyusunan tarif selain harga
PACS itu sendiri, diperlukan biaya-biaya berupa jasa Internet Service Provider, jasa instalasi perangkat keras dan lunak, back up data, listrik, AC ruang server, jasa dokter spesialis radiologi dan jasa tenaga radiografer.

Berdasarkan Keputusan Menteri Keuangan nomor 59 tahun 2013 tentang tabel masa manfaat dalam rangka penyusutan barang milik negara berupa aset tetap pada entitas pemerintah pusat, rumah sakit dr Soeradji Tirtonegoro memperkirakankan alat PACS memiliki masa manfaat / masa ekonomis 5 tahun dan pada akhir tahun ke 5 memiliki nilai sisa / residu sebesar 0 .

Jangkauan pelayanan / perkiraan pengguna PACS

Sesuai data Sistem Informasi Rumah Sakit (SIRS) online Kementerian Kesehatan Republik Indonesia pada tanggal 1 Januari 2014 bahwa saat ini ketersediaan tenaga pelayanan radiologi belum merata di fasilitas kesehatan sekunder khususnya rumah sakit kelas $\mathrm{C}$ dan $\mathrm{D}$, terutama di daerah perbatasan, terpencil dan kepulauan (DPTK). Jumlah dokter spesialis radiologi terendah berada di provinsi Sumatera Barat, Kepulauan Riau dan Bengkulu.

Kemungkinan timbulnya persaingan

Ada beberapa rumah sakit di Indonesia yang sudah mengembangkan pelayanan teleradiologi antara lain rumah sakit Cipto Mangunkusumo Jakarta, Pantai Indah Kapuk Jakarta, Pertamedika Sentul City Jakarta, Bunda Jakarta, Paru Jember, Kwaingga Papua dan Karel Satsuittubun Maluku.

\section{Analisis aspek keuangan}

\section{Metode Payback Period}

Hasil analisis investasi metode Payback Period dengan asumsi jumlah pemeriksaan / pasien tiap tahun naik 5\%, selama masa manfaat 5 tahun. Pada Tabel 4 disajikan perhitungan dengan berdasar pada asumsi 2 rumah sakit yang diampu, dan pada Tabel 5 berdasar pada 1 rumah sakit yang diampu.

Tabel 4. Perhitungan Payback Period dengan tarif Rp.120.000,00, (JP 40 \%) dan jumlah pemeriksaan 25.078 pasien 


\begin{tabular}{|c|c|c|c|c|c|c|c|}
\hline TAF & & 120.000 & & & & & \\
\hline & L PEMERIKSAAN PER & 25.078 & & & & & \\
\hline$T h$ & Uraian & & Nilai Investasi & Kas Masuk & Kas Keluar & Kas Bersih & $p P$ \\
\hline & Harga Alat & & 3.089 .300 .000 & & & & \\
\hline & & & & & & & \\
\hline & Cosh Flow Investasi & & & & & & \\
\hline 1 & Jumlah Pasien/tahun & 25.078 & & & & & \\
\hline & Pendapatan & 3.009 .360 .000 & & 3.009360 .000 & & & \\
\hline & $15+18$ & & & & 1.309 .303 .081 & & \\
\hline & & & & 3.009 .360 .000 & 1.809 .303 .051 & 1.200 .056 .919 & 1.200 .056 .919 \\
\hline 2 & Jumlah Pasien/tahur & 26.332 & & & & & \\
\hline & Pendapatan & 3.159 .828 .000 & & 3.159 .828 .000 & & & \\
\hline & $15+18$ & & & & 1.899.76B.235 & & \\
\hline & Biava Pemeliharan & $5 \%$ & & & $154.490,000$ & & \\
\hline & & & & 3.159 .828 .000 & 2.054 .258 .235 & 1.105.569.765 & 2.305 .626 .684 \\
\hline 3 & Jumlah Pasien/ tahur & 27.648 & & & & & \\
\hline & Pendapatan & 3.317 .819 .400 & & 3.317 .819 .400 & & & \\
\hline & Sha ring Pendapa tan & & & & 1.994 .756 .647 & & \\
\hline & Biaya Pemeliharan & $105 \% \%$ & & & 162.214 .500 & & \\
\hline & & & & 3.317 .819 .400 & 2.156 .971147 & 1.160 .848 .253 & 3.466 .474 .938 \\
\hline 4 & Jumlah Pasien/ tahur & 29.081 & & & & & \\
\hline & Pendapatan & 3.463 .710 .370 & & 3.483 .710 .370 & & & \\
\hline & $15+1 P$ & & & & 2.094 .494 .479 & & \\
\hline & Biava Pemeliharan & 110\%: & & & 169.939 .000 & & \\
\hline & & & & 3.483 .710 .370 & 2.264 .433 .479 & 1.219 .276 .891 & 4.685 .751829 \\
\hline 5 & Jumlah Pasien/tahur & 30.432 & & & & & \\
\hline & Pendapatan & 3.657 .895 .889 & & 3.657 .895 .8 .99 & & & \\
\hline & $15+18$ & & & & 2.199 .219 .203 & & \\
\hline & Biava Pemeliharan & $115 \%$ & & & 177.663 .500 & & \\
\hline & & & & 3.657 .895 .8 .89 & 2.376 .882703 & 1.281013 .1 .86 & 5.966 .765 .015 \\
\hline
\end{tabular}

Berdasarkan tabel diatas dapat kita hitung Payback Period sebagai berikut :

$\begin{array}{ll}\text { Total investasi } & \text { : Rp. 3.089.800.000,00 } \\ \text { Pendapatan bersih tahun ke 1 } & \text { : Rp. 1.200.056.919,00 } \\ \text { Pendapatan bersih tahun ke 2 } & \text { Rp. } 1.889 .743 .081,00 \\ & \text { : Rp. 1.105.569.765,00 } \\ \text { Rp. 784.173.316,00 }\end{array}$

Dikarenakan pendapatan bersih untuk tahun ke 3 melampaui sisa investasi dari tahun ke 2 maka dapat kita hitung sebagai berikut :

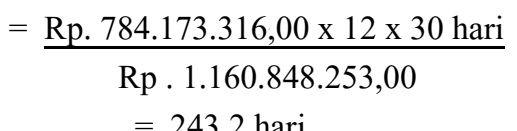

Payback Period (PP) $=2$ tahun 243,2 hari 
Tabel 5. Perhitungan Payback Period dengan tarif Rp.120.000,00, (JP $40 \%$ ) dan jumlah pemeriksaan 12.539 pasien

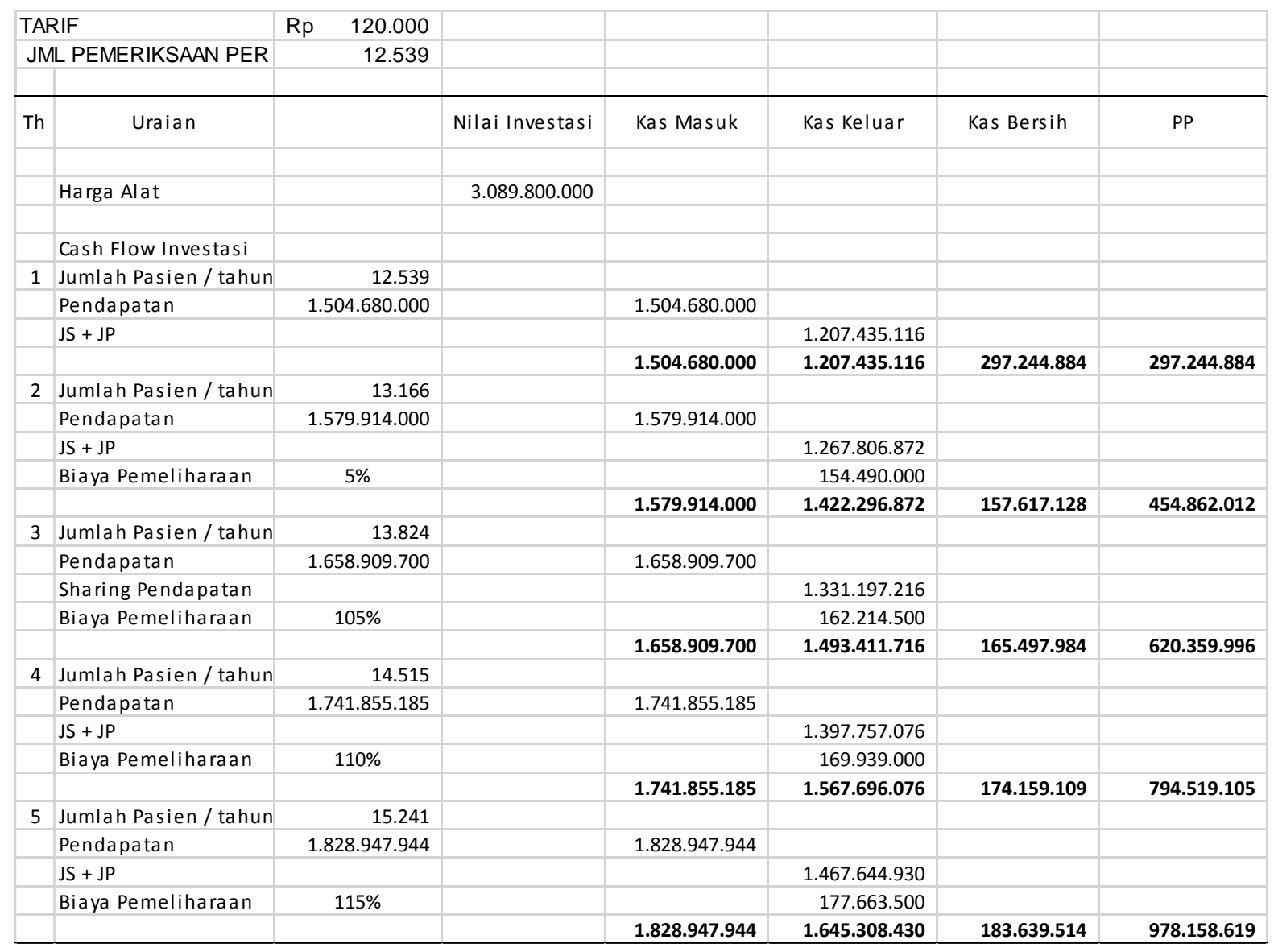

Berdasarkan Tabel 5 diatas, dapat disimpulkan bahwa Payback Period belum dapat dicapai sampai dengan tahun ke 5 .

Metode Net Present Value (NPV)

Metode ini digunakan untuk mengukur kelayakan investasi, dimana seluruh proyeksi arus kas bersih di masa depan harus dinyatakan ke dalam nilai sekarang yang dikonversikan dengan tingkat suku bunga atau discount faktor. Perhitungan Net Present Value merupakan perkalian antara Net Cash Value atau pendapatan bersih setelah pajak dikalikan dengan discount faktor. Discount faktor yang dipakai peneliti disesuaikan dengan tingkat suku bunga Bank Indonesia / BI rate saat ini yaitu 6,5\% (situs bank Indonesia per tanggal 16 Juni 2016). Dalam penelitian ini penghitungan analisis menggunakan bantuan software pengolah data Microsoft Excel version 2010.
Tabel 7. Perhitungan Net Present Value dengan discount faktor $6,5 \%$ (dengan asumsi jumlah pemeriksaan 25.078 pasien)

\begin{tabular}{cl}
\hline Data & \multicolumn{1}{c}{ Deskripsi } \\
\hline & $\begin{array}{l}\text { Tingkat diskon tahunan. } \\
\text { Menunjukkan tingkat } \\
\text { inflasi atau suku bunga } \\
\text { dari investasi yang } \\
\text { bersaing. }\end{array}$ \\
& Biaya awal investasi \\
& Laba dari tahun pertama \\
& Laba dari tahun kedua \\
1.200 .056 .919 & Laba dari tahun ketiga \\
1.105 .569 .765 & Laba dari tahun keempat \\
1.160 .848 .253 & Laba dari tahun kelima \\
\hline
\end{tabular}

Hasil Deskripsi

$1.855 .516 .083,84$ Nilai bersih saat ini untuk investasi ini 
Hasil analisis metode Net Present Value selama masa manfaat 5 tahun dapat dilihat pada tabel 7. Metode ini digunakan untuk mengukur berapa tingkat pengembalian intern yang diperoleh dari suatu investasi. Dalam penelitian ini penghitungan analisis menggunakan bantuan software pengolah data Microsoft Excel version 2010. Hasil analisis metode Internal Rate of Return selama masa manfaat 5 tahun dapat dilihat pada tabel 8 dibawah ini.

Metode Internal Rate of Return (IRR)

Tabel 8. Perhitungan Internal Rate of Return (dengan asumsi jumlah pemeriksaan 25.078 pasien)

\begin{tabular}{|c|c|}
\hline Data & Deskripsi \\
\hline$(3.089 .800 .000,00)$ & Biaya awal bisnis \\
\hline 1.200 .056 .919 & $\begin{array}{c}\text { Pendapatan bersih untuk tahun } \\
\text { pertama }\end{array}$ \\
\hline 1.105 .569 .765 & $\begin{array}{l}\text { Pendapatan bersih untuk tahun } \\
\text { kedua }\end{array}$ \\
\hline 1.160 .848 .253 & $\begin{array}{l}\text { Pendapatan bersih untuk tahun } \\
\text { ketiga }\end{array}$ \\
\hline 1.219 .276 .891 & $\begin{array}{l}\text { Pendapatan bersih untuk tahun } \\
\text { keempat }\end{array}$ \\
\hline 1.281 .013 .186 & $\begin{array}{l}\text { Pendapatan bersih untuk tahun } \\
\text { kelima }\end{array}$ \\
\hline Hasil & Deskripsi \\
\hline $26 \%$ & $\begin{array}{l}\text { Tingkat internal pengembalian } \\
\text { investasi setelah lima tahun }\end{array}$ \\
\hline
\end{tabular}

Ditinjau dari sub aspek pemilihan jenis alat PACS

Sesuai program pengembangan pelayanan teleradiologi yang dicanangkan oleh rumah sakit $\mathrm{dr}$ Soeradji Tirtonegoro, yaitu sebagai pengampu rumah sakit di Indonesia yang tidak mempunyai / masih kekurangan tenaga dokter spesialis radiologi maka memerlukan alat PACS dengan spesifikasi cloud, harga Rp.3.089.800.000,00. Alat PACS dengan harga tersebut sudah masuk dalam perencanaan / e planning anggaran Daftar Isian Pelaksanaan Anggaran (DIPA) tahun 2017.

Ditinjau dari sub aspek lokasi

Rumah sakit dr Soeradji Tirtonegoro sebagai rumah sakit pengampu, sudah mempersiapkan ruang di instalasi radiologi seluas $22,4 \mathrm{~m} 2$ untuk memenuhi kebutuhan ruangan (workstation) bagi perangkat keras maupun perangkat lunak alat PACS. Direncanakan menggunakan ruang yang saat ini digunakan untuk ruang pembacaan radiologi dengan mengalihkan beberapa mebelair yaitu 2 almari dan 1 meja ke ruang lain. Dengan melihat denah ruang yang dipersiapkan, sudah sesuai dengan keputusan Menteri Kesehatan Republik Indonesia nomor 1014/Menkes/SK/XI/2008 tentang standar pelayanan radiologi diagnostik di sarana pelayanan kesehatan untuk alat PACS.

Ditinjau dari sub aspek tenaga, berdasarkan keputusan Menteri Kesehatan Republik Indonesia nomor 1014/Menkes/SK/XI/2008 tentang standar pelayanan radiologi diagnostik di sarana pelayanan kesehatan, dimana disebutkan bahwa salah satu tugas pokok seorang spesialis radiologi adalah melaksanakan teleradiologi dan konsultasi radiodiagnostik, imejing diagnostik dan radiologi intervensional sesuai kebutuhan. Sedangkan salah satu tugas pokok seorang radiografer adalah melakukan penjaminan dan kendali mutu.

Untuk menyelenggarakan pelayanan teleradiologi dengan alat PACS diperlukan seorang spesialis radiologi untuk menerjemahkan hasil pembacaan expertise, sedangkan radiografer diperlukan sebagai pengirim gambar yang akan melakukan pengecekan apakah hasil pembacaan / report sudah terkirim atau belum (quality control), serta membantu menerjemahkan apabila hasil pembacaan / report sulit dibaca oleh penerima. Berdasarkan tabel 3, rumah sakit $\mathrm{dr}$ Soeradji Tirtonegoro memiliki 4 orang dokter spesialis radiologi, menurut Permenkes 56 tahun 2014 sudah memenuhi persyaratan minimal untuk jumlah ketena-gaan di rumah sakit klas A, akan tetapi menurut Keputusan Menteri Kesehatan RI No.1014 tahun 2008 sesuai tabel 2, belum memenuhi persyaratan minimal sehingga perlu penambahan 2 orang dokter spesialis radiologi.

Untuk tenaga radiografer, rumah sakit dr Soeradji Tirtonegoro memiliki 13 orang radiografer dengan alat $\mathrm{x}$ ray sejumlah 11 buah. Menurut Keputusan Menteri Kesehatan RI No.1014 tahun 2008, standarnya adalah 1 alat oleh 2 orang radiografer sehingga dengan adanya penambahan alat PACS seharusnya ada tambahan tenaga radiografer sebanyak 11 orang. Saat ini masih dianggap cukup sesuai hasil perhitungan analisis beban kerja oleh sub bagian sumber daya manusia dan instalasi radiologi. Selain itu, perlu dipikirkan juga beberapa kendala, antara lain: (1) Belum ada kejelasan regulasi. Indonesia baru sebatas mengaturnya dalam Keputusan Direktur Jenderal Bina Upaya Kesehatan Kementerian Kesehatan Republik Indonesia melalui Surat Keputusan Direktur Nomor: HK.02.03/V/0209/2013 Tanggal 31 Januari 2013 Tentang Pelaksanaan Pilot Project Telemedicine dan Penunjukan Fasilitas Pelayanan Kesehatan Telemedicine Bidang Teleradiologi dan Telekardiologi; $;$ (2) 
Ijin praktek dokter di Indonesia masih berdasarkan wilayah, padahal dengan pelayanan teleradiologi dokter akan otomatis berpraktek lintas wilayah, sehingga di Indonesia baru dimanfaatkan untuk internal / intranet. ${ }^{-}$

Sebagai kesimpulan, untuk menuju rumah sakit kelas A belum mampu memenuhi akan tetapi sesuai kondisi sekarang sebagai rumah sakit kelas B sudah mampu memenuhi dari sisi tenaga medis. Rumah sakit dr Soeradji Tirtonegoro telah mempertimbangkan dari sub aspek pemilihan jenis alat, lokasi dan tenaga. Dengan demikian berdasarkan gambaran kelayakan tersebut dapat disimpulkan, ditinjau dari aspek teknis pengadaan alat PACS layak diadakan oleh rumah sakit dr Soeradji Tirtonegoro.

Dari aspek pasar diperoleh gambaran kelayakan pasar sebagai berikut: (1) Terjadi penurunan kunjungan / tindakan di instalasi radiologi dalam 3 tahun terakhir, diperkirakan karena adanya kebijakan dari Badan Pelaksana Jaminan Sosial kesehatan sejak tanggal 1 Januari 2014, terjadi perubahan sistem paket klaim rawat jalan sehingga pemeriksaan penunjang sering tidak dilakukan; (2) Terjadi kerusakan alat CT Scan pada bulan September 2014 dan kembali rusak mulai pertengahan bulan Oktober 2015 sampai dengan akhir Desember 2015 sehingga tidak melayani dan dirujuk keluar rumah sakit; (3) Mulai tanggal 1 Januari 2015 tidak melayani pembacaan x-ray dental; (4) Tarif yang lebih mahal dibanding klinik dan rumah sakit lain.

Dari data menunjukkan bahwa mayoritas kekurangan tenaga kesehatan spesialis radiologi ada di rumah sakit klas C dan D milik pemerintah. Jumlah dokter spesialis radiologi terendah berada di provinsi Sumatera Barat, Kepulauan Riau dan Bengkulu. Rumah sakit yang ada di ketiga provinsi tersebut potensial menjadi rumah sakit yang diampu oleh rumah sakit $\mathrm{dr}$ Soeradji Tirtonegoro.

Rumah sakit dr Soeradji Tirtonegoro telah mengantisipasi bahwa kecil kemungkinan timbulnya persaingan. Ada beberapa alasan yaitu: ${ }^{7}$ (1) Untuk menjadi rumah sakit pengampu yang menyelenggarakan pelayanan teleradiologi kepada rumah sakit yang diampu harus didukung dengan pelayanan dokter spesialis radiologi yang cukup jumlahnya; (2) Alat PACS merupakan syarat peralatan yang harus ada di rumah sakit klas A, sementara di Indonesia hanya beberapa rumah sakit yang sudah mempunyai alat tersebut.

\section{Perkiraan umur ekonomis dan tarif yang layak}

Di dalam buku Pedoman Pengelolaan Peralatan Kesehatan di Fasilitas Pelayanan Kesehatan yang disusun oleh Direktorat Bina Pelayanan Penunjang Medik dan Sarana Kesehatan, Direktorat Jenderal Bina Upaya Kesehatan (2015) menyebutkan bahwa dalam penilaian teknologi peralatan perlu dipertimbangkan juga Life cycle cost (LCC) sebagai salah satu instrument penilaian, selain Ijin Edar. Life cycle cost (LCC) adalah total biaya keseluruhan peralatan, termasuk biaya pembelian, pengoperasian, pemeli-haraan, pengalihan dan atau penghapusan. LCC merupakan model ekonomi selama masa dari peralatan tersebut dipakai, dipelihara, dihapus, biasanya sebesar 2 - 20 kali lebih besar dari biaya pengadaan awal. Keseimbangan antara unsurunsur biaya dicapai ketika total LCC bisa diminimalkan. Perkiraan biaya pemeliharaan selama setahun adalah sekitar 5\% sampai $6 \%$ dari nilai investasi peralatan medis. Besaran biaya pemeliharaan peralatan medis masing masing rumah sakit bisa berbeda.

Sesuai pasal 9 Peraturan Pemerintah nomor 23 tahun 2005 tentang pola tarif Badan Layanan Umum, tarif harus mempertimbangkan: (1) Kontinuitas dan pengembangan layanan; (2) Daya beli masyarakat; (3) Asas keadilan dan kepatutan; dan (4) Kompetisi yang sehat. Oleh karena beberapa pertimbangan diatas dan disetarakan dengan tarif yang berlaku di RSST untuk pemeriksaan radiologi rawat jalan kategori sederhana, tarif yang diperhitungkan dalam penelitian ini adalah sebesar Rp. 120.000,00 dengan prosentase jasa pelayanan sebesar $40 \%$. Hal ini sesuai dengan Peraturan Menteri Kesehatan nomor 12 tahun 2013 tentang pola tarif Badan Layanan Umum pasal 28 bahwa besaran jasa pelayanan maksimal $44 \%$ dari jumlah tarif. Tarif tersebut bisa bersaing dengan tarif Rp. 162.000,00 yang berlaku di rumah sakit pesaing Narayana Netralaya Healthcare negara India.

Rumah sakit dr Soeradji Tirtonegoro telah mempertimbangkan dari sub aspek perkiraan permintaan, kemungkinan timbulnya persaingan, perkiraan umur ekonomis dan tarif yang layak. Dengan demikian berdasarkan gambaran kelayakan tersebut dapat disimpulkan, ditinjau dari aspek pasar pengadaan alat PACS layak diadakan oleh rumah sakit dr Soeradji Tirtonegoro. 
Dari

keuangan

Pengembangan alat PACS membutuhkan investasi sebesar Rp. 3.089.800.000,-- Pengembangan alat tersebut direncanakan menggunakan 100\% anggaran Daftar Isian Pelaksanaan Anggaran (DIPA) dari pemerintah Republik Indonesia dan sudah masuk dalam e planning tahun 2017. Nilai aset dari investasi keseluruhan untuk pengembangan alat PACS sebesar Rp. 3.089.800.000,00. Tabel 5 menun-jukkan bahwa tarif Rp. 120.000,00 serta utilisasi sesuai perkiraan permintaan yaitu 25.078 pemeriksaan dengan asumsi tiap tahun naik 5\%, diperkirakan aliran kas masuk selama tahun 2017 sampai dengan tahun 2021 sebesar Rp. 16.628.613.659,00, aliran kas keluar sebesar Rp. 10.661.848.645,00, sehingga aliran kas bersih selama umur investasi sebesar Rp. 5.966.765.014,00. Berdasarkan perhitungan / analisa Payback Period yang telah dilakukan, pada tabel 5 terlihat bahwa tarif Rp. 120.000,00 (JP 40 \%) dengan asumsi 25.078 jumlah pemeriksaan, investasi / modal akan kembali dalam jangka waktu 2 tahun 243,2 hari. Pada tabel 6 menunjukkan bahwa tarif Rp. 120.000,00 (JP 40 \%) dengan asumsi 12.539 jumlah pemeriksaan, sampai dengan tahun ke lima (5) investasi / modal belum dapat kembali. Dalam perhitungan NPV diperlukan discount factor berdasarkan suku bunga bank yang berlaku saat itu. Suku bunga Bank Indonesia / BI rate yang berlaku pada semester 1 tahun 2016 adalah 6,5\%, sehingga discount factor yang digunakan adalah $6,5 \%$. Berdasarkan perhitungan di atas pada tabel 7, dengan asumsi jumlah pemeriksaan 25.078 pasien, didapatkan nilai Rp.1.855.516.083,84. NPV bernilai positif dan nilainya $>0$, maka rencana pengembangan investasi yang akan dilakukan layak untuk dilakukan. Berdasarkan perhitungan diatas pada tabel 8 , nilai IRR yang diperoleh adalah sebesar $26 \%$, lebih besar dari suku bunga Bank Indonesia yang berlaku sebesar 6,5 \% maka IRR diterima.

\section{SIMPULAN}

Kelayakan aspek teknis: RSUP dr Soeradji Tirtonegoro telah mempertimbangkan dari sub aspek pemilihan jenis alat, lokasi, dan tenaga, dan layak untuk diadakan. Kelayakan aspek pasar : rumah sakit yang direncanakan sebagai jejaring yaitu Sumatera Barat, Kepulauan Riau dan Bengkulu potensial menjadi rumah sakit yang diampu oleh RSUP dr Soeradji Tirtonegoro dan kecil kemungkinan timbulnya persaingan karena dari beberapa rumah sakit di Indonesia yang sudah menerapkan telera-diologi, hanya 4 rumah sakit yang menggunakan alat PACS dan penggunaannya masih sebatas lokal. Dengan demikian ditinjau dari aspek pasar pengadaan alat PACS layak. Kelayakan aspek keuangan: berdasarkan hasil perhitungan dengan metode PP, NPV dan nilai IRR maka investasi alat PACS layak untuk dilakukan.

Dari hasil temuan penelitian ini maka disarankan perlu upaya promosi yang intensif untuk dapat menjalin kerjasama dengan minimal 2 rumah sakit yang diampu, dengan target jumlah pemeriksaan sebesar 25.078 pasien pada tahun pertama dan kenai-kan $5 \%$ tiap tahun. Rumah sakit perlu mengantisipasi kemungkinan terjadinya hambatan dalam jaringan internet dan mengevaluasi kebijakan tarif yang berlaku.

\section{DAFTAR PUSTAKA}

1. Dewi, SL, 2013, 'Kebijakan untuk daerah dengan jumlah tenaga kesehatan rendah', Jurnal Kebijakan Kesehatan Indonesia, volume 02, nomor 1.

2. Hariri,A, 2015, 'HIS, RIS, PACS dan teleradiologi', Portal Radiografi, 5 Agustus

3. Wotulo, Deki, 2009, 'Analisis

4. kelayakan investasi alat foto rontgen panoramik di RSUD Undata Palu Propinsi Sulawesi Tengah', Tesis Magister Ilmu Kesehatan Masyarakat UGM, Yogyakarta.

5. Hidayati, Nur, 2004, 'Evaluasi kelayakan investasi alat medis bone densitometer rumah sakit daerah Panembahan Senopati Bantul', Tesis Magister Manajemen Rumah Sakit UGM, Yogyakarta.

6. Luthfi, 2014, 'Telemedicine, Layanan Medis Jarak Jauh', Teknopreneur.com, Jakarta.

7. Harlan, Johan, 2012, 'Teleradiologi di Indonesia Belum Berkembang', Kebijakan Kesehatan Indonesia, 24 Oktober 2012. 